\title{
日本新産鉱物情報（2021年）＜wide>松原 聰
}

日本新産鉱物情報（2020年）以降，2021年12月末までに確認された日本産新鉱物および新産鉱物，その他について紹介 する．太字は少なくとも化学的，結晶学的性質が明らかにされたもので，信頼度が高い，

\section{元素鉱物}

安金鉱 Aurostibite $\mathrm{AuSb}_{2}$ 立方 北海道羽幌町愛奴 沢川

Nishio-Hamane \& Saito, JMPS, 116, 263-271 (2021).

河川堆積物中の砂金粒に伴って，20 $\mu \mathrm{m}$ 以下の不規則 な粒として産する。

鉛金鉱 Anyuiite $\mathrm{Au}(\mathrm{Pb}, \mathrm{Sb})_{2}$ 正方 北海道羽幌町愛 奴沢川

Nishio-Hamane \& Saito, JMPS, 116, 263-271 (2021).

河川堆積物中の砂金粒に伴って，20 $\mu \mathrm{m}$ 以下の不規則 な粒として産する。

\section{硫化鉱物}

銅砒四面銅鉱 Tennantite- $(\mathrm{Cu}) \quad \mathrm{Cu}_{6}\left(\mathrm{Cu}_{4} \mathrm{Cu}_{2}\right) \mathrm{As}_{4} \mathrm{~S}_{13}$ 立 方 北海道手稲鉱山

松原ほか（未発表）。

四面銅鉱のなかまの命名法が定義された（Biagioni et al., 2020）ことにより新たにできた新鉱物（原産地はペルー Layo deposit, IMA 2020-096）．最近，手稲鉱山の輝蒼鉛鉱 などに伴うものを分析したところ確認された.この鉱物の 産地は今のところ日本ではここだけ.

$$
\text { 安ゴールドフィールド鉱 Stibiogoldfieldite }
$$

$\mathrm{Cu}_{6} \mathrm{Cu}_{6}\left(\mathrm{Sb}_{2} \mathrm{Te}_{2}\right) \mathrm{S}_{13}$ 立方 静岡県河津鉱山(猿喰坑ほか), 鹿児島県入来鉱山，北海道手稲鉱山，北海道札幌市新大豊 鉱床

Shimizu \& Stanley, Mineralogical Magazine, 55, 515-519 (1991); Imai et al., Resource Geology, 49, 75-88 (1999); 島倉 ほか，北大地球物理研報，78,19-35 (2015); 松原ほか（未 発表）.

Stibiogoldfielditeは, 四面銅鉱グループの命名法が定義さ れたことにより生じた新鉱物（IMA 2020-104,アメリカの Mohawk鉱山が原産地. もちろんゴールドフィールド鉱の 原産地でもある）。新たに定義されたゴールドフィールド 鉱の理想化学式は $\left(\mathrm{Cu}_{4} \square_{2}\right) \mathrm{Cu}_{6} \mathrm{Te}_{4} \mathrm{~S}_{13}$ となり，従来この名称 で知られていた日本産のものを再検討する必要が出てき た．そこで，過去の分析值などを検討したところ，上記4 産地のものが安ゴールドフィールド鉱に該当した. 河津鉱 山猿喰坑のものは松原ほかが分析したが，Shimizu \& Stanley (1991)の河津鉱山産は，坑の出所が未記載である. なお, $\mathrm{Cu}_{6} \mathrm{Cu}_{6}\left(\mathrm{As}_{2} \mathrm{Te}_{2}\right) \mathrm{S}_{13}$ は現時点で知られていないので 新鉱物候補となる（名称はArsenogoldfielditeが望ましい） が，この化学組成に近いものがすでに河津鉱山（櫻井・加 藤，1970年鉱物学会講演要旨）から報告されている。この 報告で使われたと思える掛橋坑産試料（櫻井標本）

（NSN-M31554）を最近再検討したところ，間違いなく “Arsenogoldfieldite”に相当することがわかった．また，入 来鉱山（Shimizu \& Stanley, 1991）の分析值の2つ（no. 4 と no. 5) も“Arsenogoldfieldite”に該当する.

その結果，以上の4産地から，新たに定義されたゴール
ドフィールド鉱に該当する分析值が見当たらなくなった ので, ゴールドフィールド鉱は日本産鉱物種からとりあえ ず削除しておく。

\section{酸化鉱物}

ヘンリーマイヤー石 Henrymeyerite $\mathrm{Ba}\left(\mathrm{Ti}_{7} \mathrm{Fe}^{2+}\right) \mathrm{O}_{16}$ 正方 岡山県大佐山

浜根・田邊, 日本鉱物科学会講演要旨，R1P-09 (2021) 翡翠輝石岩中にタウソン石, ストロナルシ石, スローソ ン石，シャンド鉱などと伴に確認されている.

\section{リン酸塩鉱物}

桐生石 Kiryuite $\mathrm{NaMnAl}\left(\mathrm{PO}_{4}\right) \mathrm{F}_{3}$ 単斜 群馬県桐 生市梅田町津久原

Nishio-Hamane et al., CNMNC Newsletter 63, Mineralogical Magazine, 85, 910-915 (2021).

トリプル石の分解物，あるいはそれのクラック中に，白 色板状の結晶として産する.ゴルセイ石，ゴヤ石などに伴 う.ビータニエミ石のCaをMnが置換したもの．新鉱物と して承認（IMA2021-041）。

\section{ケイ酸塩鉱物}

セリウムトルネボム石 Törnebohmite-(Ce)

$\mathrm{Ce}_{2} \mathrm{Al}\left(\mathrm{SiO}_{4}\right)_{2}(\mathrm{OH})$ 単斜 岡山県大佐山 浜根・田邊，日本鉱物科学会講演要旨，R1P-09 (2021).

翡翠輝石岩中の角閃石脈中に，淡緑黄色の $2 \sim 3 \mathrm{~mm}$ 板状 集合体として産する。また，灰褐色のモナズ石や褐策石を 覆う産状もある。なお，系魚川地区の翡翠輝石岩中にも産 出が知られていたが (宮島ほか)，未発表であった。

$$
\text { デーリー石 Dalyite } \mathrm{K}_{2} \mathrm{ZrSi}_{6} \mathrm{O}_{15} \text { 三斜 愛媛県上島町 }
$$
岩城島

Imaoka et al., 地学雑誌， 130, 369-378 (2021).

肉眼的なエジリン輝石を含む曹長岩中に, 微細なジルコ ン，フッ素燐灰石，モナズ石などと伴に $20 \mu \mathrm{m}$ 程度の結晶 として含まれる. 
ゼッツェル石 Zektzerite $\mathrm{LiNaZrSi}_{6} \mathrm{O}_{15}$ 直方 愛媛 県上島町岩城島

Imaoka et al., 地学雑誌, 130, 369-378 (2021).

肉眼的なエジリン輝石を含む曹長岩中に, 微細なジルコ ン，フッ素燐灰石，モナズ石などと伴に $20 \mu \mathrm{m}$ 程度の結晶 として含まれる。

\section{鉄葡萄石 Ferriprehnite $\mathrm{Ca}_{2} \mathrm{Fe}^{3+}\left(\mathrm{AlSi}_{3}\right) \mathrm{O}_{10}(\mathrm{OH})_{2}$ 直 方 島根県松江市古浦ヶ鼻}

Nagashima et al., JMPS, 116, 129-139 (2021).

熱水変質を受けたドレライト中に, バビントン石, 葡萄 石，ジュルゴルド石，方解石，カルシウムトムソン沸石な どと共存して産する. 板状結晶の放射状集合体などをなす. 結晶は, 無色〜淡緑色で, 最大 300 x $100 \mu \mathrm{m}$ 角, 厚さ $50 \mu \mathrm{m}$. 6 配位の $\mathrm{Al}$ が $\mathrm{Fe}^{3+}$ で置換された葡萄石で，新鉱物として承 認（IMA 2020-057）。

\section{有機鉱物}

フーウェル石 Whewellite $\mathrm{Ca}\left(\mathrm{C}_{2} \mathrm{O}_{4}\right) \cdot \mathrm{H}_{2} \mathrm{O}$ 単斜 京 都府和束町石寺

白勢ほか，日本鉱物科学会講演要旨，R1P-07 (2021)

石英中のフッ素燐灰石の変質部に，ウェッデル石，クラ ンダル石 - フローレンス石系鉱物を伴って，白濁した塊 状～膜状集合として産する. 幅約 $5 \mu \mathrm{m}$ の板状結晶からな る約 $20 \mu \mathrm{m}$ の球状集合として見られる。

\section{付録}

日本新産鉱物情報 (2020年以前)で紹介した鉱物のうち， その後論文化されたものについて, その雑誌名を掲げてお $<$.

アルミノ杉石（原記載のもの） Nagashima et al., European Journal of Mineralogy, 32, 57-66 (2020).

ザイール石 Morimitsu et al., JMPS, 116, 104-107 (2021).

留萌鉱，初山別鉱，ユアンジャン（沅江）鉱，自然鉛

Nishio-Hamane \& Saito, JMPS, 116, 263-271 (2021). 